\title{
Effect of foliar urea spraying and nitrogen application at sowing upon dry matter and nitrogen distribution in wheat (Triticum aestivum L)
}

\author{
SJ Sarandón*, MC Gianibelli* \\ Cátedra de Cerealicultura, Facultad de Agronomia, Universidad Nacional de La Plata, \\ CC 31 (1900) La Plata, Argentina
}

(Received 27 October 1987 ; accepted 20 November 1989)

\begin{abstract}
Summary - The effects of foliar urea spraying at field level at 3 different developmental wheat stages upon grain yield, its components, and $\mathrm{N}$ accumulation and distribution within the plant were studied on Buck Pucará, a cultivar with Mexican germplasm and high grain yielding potential. Plants were grown at $2 \mathrm{~N}$ levels: no $\mathrm{N}$ and $100 \mathrm{~kg} \mathrm{~N}$ ha applied at sowing as granular urea, without (control) and with foliar urea spraying $\left(20 \mathrm{~kg} \mathrm{~N} / \mathrm{ha}\right.$ ) at the end of tillering ( $\left.T_{1}\right)$, at anthesis $\left(T_{2}\right)$, or 14 days after anthesis $\left(T_{3}\right)$. Spraying at $T_{1}$ increased ear number $/ \mathrm{m}^{2}$, biological yield, grain yield, harvest index, total $N$ uptake and nitrogen harvest index. It also increased grain set, without affecting fertile spikelet/spike. Spraying at $\mathrm{T}_{2}$ or afterwards, increased grain $\% \mathrm{~N}$ and plant $\% \mathrm{~N}$ at maturity but did not improve $\mathrm{N}$ allocation in the grain, grain yield and its components. Spraying at $\mathrm{T}_{1}$ only increased grain $\% \mathrm{~N}$, total $\% \mathrm{~N}$ and $\% \mathrm{~N}$ of the vegetative organs when $\mathrm{N}$ availability at sowing was high.
\end{abstract}

nitrogen / urea / wheat / yield / foliar spraying / biomass

Résumé - Effet de l'application d'une fumure azotée au semis et d'une pulvérisation foliaire d'urée sur la répartition de matière sèche et de l'azote dans le blé (Triticum aestivum $\mathrm{L}$ ). On étudie, sur des parcelles de blé ayant ou non reçu de l'engrais azoté au semis (100 kg/ha), l'effet d'une application foliaire d'urée sur le rendement en grain, ses composantes et la répartition de l'azote entre organes. L'essai est réalisé au champ à La Plata (Argentine) avec le cultivar Buck Pucará, caractérisé par un potentiel de production élevé. Pour chaque modalité de fertilisation au semis, 4 traitements différents, qui concernent la fertilisation foliaire, sont mis en place: $C=$ témoin sans fertilisation ; $T_{1}=20 \mathrm{~kg} \mathrm{~N} / \mathrm{ha}$ à la fin du tallage; $T_{2}=20 \mathrm{~kg} \mathrm{~N} / \mathrm{ha}$ à l'anthèse; $T_{3}=20 \mathrm{~kg} \mathrm{~N} / \mathrm{ha} 14$ jours après l'anthèse. L'application de l'azote au semis modifie la production de matière sèche et sa répartition à maturité : le rendement en grain est augmenté avec un indice de récolte plus faible (tableau I). La pulvérisation foliaire d'urée au tallage augmente le nombre d'épis $/ \mathrm{m}^{2}$, le nombre de grains/épillet, la biomasse, le rendement en grains et l'indice de récolte (HI) (tableaux let II). Mais le nombre d'épillets fertiles par épi et le poids d'un grain restent inchangés. La quantité d'azote absorbé et

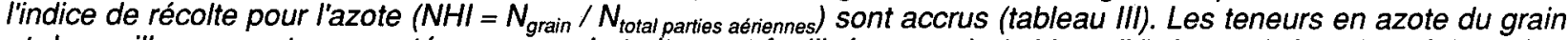
et des pailles ne sont augmentées que sur le traitement fertilisé au semis (tableau IV). Les pulvérisations à l'anthèse et après celle-ci augmentent la teneur en azote du grain et de la plante entière à maturité mais n'affectent ni le rendement, ni ses composantes, ni les indices de récolte (HI et NHI) (tableaux I, II et IV).

foliaire / biomasse / urée / blé / rendement / pulvérisation

\section{INTRODUCTION}

Nitrogen availability during crop growth is a determining factor for grain yield and grain protein percentage in wheat. Nitrogen fertilization at sowing commonly increases grain yield as a result of increases in ear number $/ \mathrm{m}^{2}$. However, this increase in ear number $/ \mathrm{m}^{2}$ is widely associated with a decrease in harvest index (Darwinkel, 1979; Donald, Hamblin, 1976). Furthermore, not all the tillers produced by $\mathrm{N}$ fertilization at sowing bear ears at maturity. To minimize this, $\mathrm{N}$ applications can be delayed until the time of tillering. (Coic, 1960; Scott et al, 1977).

* Assistant researchers from the Scientific Research Board (CIC) of Buenos Aires. 
It is well known that early nitrogen supply generally increases yield and decreases grain protein percentage, especially when $\mathrm{N}$ supply is low (Fernandez, Laird, 1959). This is in agreement with the inverse relationship between yield and grain protein percentage (Kramer, 1979; Mesdag, 1979; Terman, 1979; Loffler et al, 1985).

Scholz (1984) claimed out that protein production could be improved by increasing plant $\mathrm{N}$ absorption or $\mathrm{N}$ translocation from the vegetative structures towards the grain. A low genetical variation has been found in wheat for plant $\mathrm{N}$ uptake (Johnson et al, 1968; Dubois, Fossati, 1981; Sarandón, Chidichimo, 1985), then the most effective way to obtain high grain protein yield might be to increase $\mathrm{N}$ allocation in the grain.

High $\mathrm{N}$ availability increased $\mathrm{N}$ content and percentage in the plant whereas it diminished $\mathrm{N}$ distribution to the grain (Neales et al, 1963; Andersen, Koie, 1975; Halloran, 1981). However, late $\mathrm{N}$ applications during crop growth, for example urea spraying, effectively increases grain protein percentage (Finney et al, 1957; Sarandón et al, 1986). Nevertheless, the origins of this positive increment in grain protein content remain unknown.

The aim of this work was to study the effects of $\mathrm{N}$ fertilization at sowing and foliar urea spraying at 3 developmental stages upon grain yield and its components, $\mathrm{N}$ accumulation and distribution and their relationship with grain $\% \mathrm{~N}$ in a wheat cultivar of high yielding potential.

\section{MATERIALS AND METHODS}

The assay was carried out in the field at the Gorina Experimental Station, La Plata (SL 34 54'), Ecological Subregion II South, in a clay loamy soil. Weather conditions in the trial location are characterized by a mild climate without dry season and mean temperatures of $9^{\circ} \mathrm{C}$ during winter and $22^{\circ} \mathrm{C}$ during summer. Annual rainfall is around $970 \mathrm{~mm}$. Weather conditions during crop growth are shown in fig 1.

Buck Pucará -BP- (Triticum aestivum L) a cultivar with Mexican germplasm and high yielding potential was used. Sowing was carried out on July 11 at a density of 250 plants $/ \mathrm{m}^{2}$, in a randomized block design with 4 replications (each plot $7.70 \mathrm{~m}^{2} ; 5.50 \times 1.20 \mathrm{~m}$ ). Soil analysis at sowing showed: carbon: $2.92 \%$; total $\mathrm{N}: 0.26 \%$; N-nitrates: $23 \mathrm{mg} / \mathrm{kg}$; available phosphorus: $7.0 \mathrm{mg} / \mathrm{kg}$ and carbon/nitrogen: 11 .

From these data $100 \mathrm{~kg} / \mathrm{ha}$ of NPK (0-46-0) were applied. At that moment, granular urea, $100 \mathrm{~kg} \mathrm{~N} / \mathrm{ha}$ (46-0-0) was also applied to half the plots (NS), while the other half remained without $N$ (NNS). In addition, a $12 \%$ commercial urea solution plus a wetting agent was sprayed at $20 \mathrm{~kg} \mathrm{~N} / \mathrm{ha}$ at the end of tillering $\left(T_{1}\right)$,

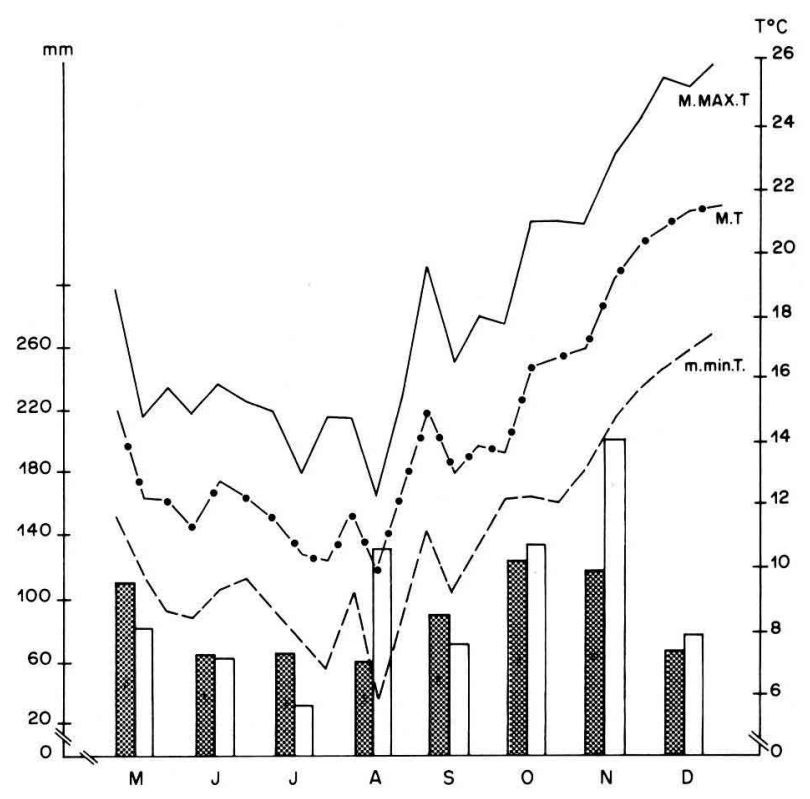

Fig 1. Monthly rainfall and weekly temperatures during crop development in 1986. M.Max $T=$ mean maximum temperature: $M T=$ mean temperature; $\operatorname{m} . \min . T=$ mean minimum temperature. White bars represent the mean of rainfall during 1986. Grey bars represent the mean rainfall for several years.

anthesis $\left(T_{2}\right)$ and 2 weeks after anthesis $\left(T_{3}\right)$. Control plots were not subjected to spraying.

Urea spraying at tillering (September 29) coincided with stages 22-25 of Tottman et al (1979) in NNS plots and with stage 31 in NS. At that moment the apex was at the terminal spikelet stage. Anthesis (3 October) coincided with stage 69.

At maturity (12 December) 3 rows (each fraction $0.50 \mathrm{~m}$ long) per plot were harvested. Plants were cut at ground level, separated into leaves, stems, chaff and grain (harvest index - HI-) and dried at $70^{\circ} \mathrm{C}$ during $48 \mathrm{~h}$. The biological yield was considered as the total aerial dry matter production.

The material was ground in a Cyclone Sample Mill (UDY), for humidity determination. Nitrogen percentage of each plant fraction was determined by the Micro Kjeldahl method (43-13, AACC, 1983). Nitrogen harvest index (NHI) was calculated as grain $\mathrm{N} /$ total plant $\mathrm{N}$ (grain + straw + chaff). The ratio $\mathrm{NHI/HI}$ was analyzed to evaluate the influences of fertilization upon the relative efficiency of dry matter and nitrogen distribution.

An analysis of variance was performed and differences determined by Tukey test $(P \leq 0.05)$.

\section{RESULTS}

\section{Effect upon dry matter accumulation and distribution, grain yield and its components}

Nitrogen application at sowing (NS) modified dry matter production and partitioning at maturity (table 1), increasing grain yield $43 \%$ and biological yield $65 \%$, which resulted in a low harvest index. The number of fertile spikelets per spike was increased, but a decrease in grain 
number per spikelet led to no significant difference in grain number per spike (table II).

$\mathrm{N}$ application at sowing increased grain number per $\mathrm{m}^{2}$ which was the most important factor in relation to grain yield $\left(r=0.992^{\star \star}\right)$. It depended more on ears per $\mathrm{m}^{2}\left(r=0.900^{\star *}\right)$ than on grain number per spike $\left(r=0.392^{*}\right)$, which was not significantly modified.
Urea spraying at tillering $\left(T_{1}\right)$ increased ear number per $\mathrm{m}^{2}$, biological yield $(30 \%)$, grain yield $(48 \%)$ and harvest index. Fertile spikelet number per spike was not modified by $N$ spraying, though in $\mathrm{T}_{1}$ grain set was improved, thus grain number per spikelet, grain number per spike and ear weight were higher in this treatment. The increase in grain number per $\mathrm{m}^{2}$ resulted from an

Table I. Effect of foliar nitrogen fertilization upon grain yield and dry matter distribution.

(1) Least significant differences between treatments within each fertility condition. (2) Least significant differences between fertility conditions. ns = no significative.

\begin{tabular}{|c|c|c|c|c|c|c|}
\hline \multirow[t]{2}{*}{ Treatments } & \multirow{2}{*}{$\begin{array}{r}\mathrm{kg} / \mathrm{ha} \\
\text { biol } \\
\text { yield }\end{array}$} & \multirow{2}{*}{$\begin{array}{l}\mathrm{kg} / \mathrm{ha} \\
\text { grain } \\
\text { yield }\end{array}$} & \multicolumn{4}{|c|}{ dry matter distribution (\%) } \\
\hline & & & Leaf & Stem & Chaff & $\begin{array}{c}\text { Grain } \\
(H I)\end{array}$ \\
\hline \multicolumn{7}{|c|}{ No $\mathrm{N}$ at sowing } \\
\hline Control & 7760 & 3200 & 15.7 & 33.3 & 10.0 & 41.1 \\
\hline $\mathrm{T}_{1}$ & 11330 & 5166 & 13.6 & 30.5 & 10.4 & 45.5 \\
\hline $\mathrm{T}_{2}$ & 8640 & 3570 & 15.7 & 32.9 & 10.0 & 41.4 \\
\hline $\mathrm{T}_{3}$ & 7790 & 3230 & 15.7 & 31.8 & 11.0 & 41.5 \\
\hline Average & 8881 & 3791 & 15.2 & 32.1 & 10.3 & 42.2 \\
\hline \multicolumn{7}{|l|}{$\mathrm{N}$ at sowing } \\
\hline Control & 13820 & 4810 & 18.5 & 38.5 & 8.2 & 34.8 \\
\hline $\mathrm{T}_{1}$ & 16570 & 6650 & 17.0 & 34.0 & 9.0 & 40.1 \\
\hline $\mathrm{T}_{2}$ & 14260 & 5190 & 17.6 & 37.5 & 8.5 & 36.4 \\
\hline $\mathrm{T}_{3}$ & 14040 & 5020 & 16.4 & 37.2 & 10.7 & 35.8 \\
\hline Average & 14673 & 5415 & 17.4 & 36.8 & 9.1 & 36.8 \\
\hline LSD (1) & 2515 & 1174 & 2.6 & 3.3 & 5.4 & 4.4 \\
\hline LSD (2) & 936 & 437 & 0.97 & 1.2 & 2.0 & 1.6 \\
\hline Interaction & ns & ns & ns & ns & ns & ns \\
\hline
\end{tabular}

Table II. Effect of foliar nitrogen fertilization upon several yield components.

(1) Least significant differences between treatments within each fertility condition. (2) Least significant differences between fertility conditions (ns and nns).

\begin{tabular}{|c|c|c|c|c|c|c|c|}
\hline Treatments & $E a r / m^{2}$ & $\begin{array}{c}\text { Fertile } \\
\text { spikelet } \\
\text { number/spike }\end{array}$ & $\begin{array}{c}\text { Grain } \\
\text { number' } \\
\text { spikelet }\end{array}$ & $\begin{array}{l}\text { Grain } \\
\text { number/ } \\
\text { spike }\end{array}$ & $\begin{array}{c}\text { Kernel } \\
\text { weight } \\
(m g)\end{array}$ & $\begin{array}{l}\text { Weight } \\
\text { per } \\
\text { spike }\end{array}$ & $\begin{array}{c}\text { Grain } \\
\text { number } \\
m^{2}\end{array}$ \\
\hline \multicolumn{8}{|l|}{ No $N$ sowing } \\
\hline Control & 324 & 14.1 & 2.0 & 27.9 & 35.2 & 1.22 & 9096 \\
\hline$T_{1}$ & 468 & 14.0 & 2.1 & 29.9 & 36.9 & 1.35 & 13995 \\
\hline $\mathrm{T}_{2}$ & 370 & 14.1 & 1.9 & 27.1 & 35.5 & 1.20 & 10062 \\
\hline$T_{3}$ & 343 & 14.1 & 1.9 & 27.3 & 34.5 & 1.19 & 9352 \\
\hline Average & 376 & 14.1 & 2.0 & 28.0 & 35.5 & 1.24 & 10626 \\
\hline \multicolumn{8}{|l|}{$\mathrm{N}$ at sowing } \\
\hline Control & 544 & 14.6 & 1.7 & 24.5 & 36.3 & 1.10 & 13239 \\
\hline$T_{1}$ & 581 & 15.7 & 2.0 & 30.6 & 35.9 & 1.40 & 18513 \\
\hline $\mathrm{T}_{2}$ & 532 & 15.2 & 1.7 & 24.1 & 37.4 & 1.29 & 13877 \\
\hline $\mathrm{T}_{3}$ & 530 & 15.0 & 1.8 & 26.7 & 35.5 & 1.23 & 14135 \\
\hline Average & 547 & 15.1 & 1.8 & 27.0 & 36.2 & 1.25 & 14941 \\
\hline LSD (1) & 101 & 1.16 & 0.14 & 3.40 & 1.70 & 0.13 & 3146 \\
\hline LSD (2) & 37.4 & 0.43 & 0.05 & 1.26 & 0.63 & 0.05 & 1170 \\
\hline Interaction & ns & ns & ns & ns & * & * & ns \\
\hline
\end{tabular}

*P $P$ *0.05;

** $P \leq 0.01$ 
increase of ears per $\mathrm{m}^{2}$ and of grain number per spike (table II).

Nitrogen application at sowing and spraying at tillering only modified parameters related with grain number per $\mathrm{m}^{2}$, but not in kernel weight. Treatments at anthesis $\left(T_{2}\right)$ and post-anthesis $\left(T_{3}\right)$ neither affected grain yield nor its components (tables I and II).

\section{Effect upon nitrogen accumulation and redistribution}

At maturity, total $\mathrm{N}$ uptake ranged between 74 and $146 \mathrm{~kg} / \mathrm{ha}$ and was higher for the plots receiving $\mathrm{N}$ at sowing (table III). Urea spraying also increased it, but treatments at anthesis and post-anthesis had less effect. Nitrogen application at sowing reduced nitrogen distribution efficiency to the grain (NHI), but improved the relationship $\mathrm{NHI} / \mathrm{HI}$.

Nitrogen application at sowing also diminished grain \% $\mathrm{N}$ and total $\% \mathrm{~N}$ in the plant (table IV). All $\mathrm{N}$ spraying treatments, excluding that performed at tillering $\left(T_{1}\right)$ on plots without $N$ at sowing, increased total plant \% $\mathrm{N}$, which was inversely related $\left(r=-0.736^{*}\right)$ to the biological yield. Spraying at tillering $\left(\mathrm{T}_{1}\right)$ decreased grain $\% \mathrm{~N}$ in plots that had no $\mathrm{N}$ at sowing. Later sprayings $\left(\mathrm{T}_{2}\right.$ and $\mathrm{T}_{3}$ ) increased grain $\mathrm{N} \%$, independently of $\mathrm{N}$ treatment at sowing (table IV).

\section{DISCUSSION}

Grain yield was increased by sowing fertilization due to a greater number of ears per $\mathrm{m}^{2}$, confirming that early $\mathrm{N}$ availability promotes tiller formation (Langer, 1966). When water is not a limiting factor, as in this experiment, early $\mathrm{N}$ applications induce greater vegetative growth and a higher $\mathrm{N}$ consumption by tillers that, sometimes do not form heads, but exerts competition for resources at some developmental stages. The importance of this competition depends on when it takes place and on the yield component affected at that time. In this assay, competition was operating upon grain set, decreasing grain number per spikelet and ear weight. This resulted in a decrease in harvest index, which is consistent with a less efficient dry matter distribution at high densities (Donald, Hamblin, 1976; Darwinkel, 1979). The increase in grain number per spikelet, as observed when $\mathrm{N}$ was sprayed at anthesis, shows that nitrogen can act as a limiting factor, even when the crop is fertilized at sowing.

When $\mathrm{N}$ was applied at tillering, head population increased, showing that nitrogen

Table III. Effect of foliar $\mathbf{N}$ fertilization upon $\mathrm{N}$ distribution at maturity.

(1) Least significant differences between treatments within each fertility conditions. (2) Least significant differences between fertility conditions ( $\mathrm{ns}$ and nns).

\begin{tabular}{lccccc}
\hline Treatments & $\begin{array}{c}\text { Total } N \\
\text { uptake } \\
\mathrm{kg} / \mathrm{ha}\end{array}$ & $\begin{array}{c}\text { grain } \\
(\mathrm{NHI})\end{array}$ & $\begin{array}{c}\text { Nitrogen distribution (\%) } \\
\text { Leaf }\end{array}$ & Stem & NHI/HI \\
\hline No N at sowing & & & & & \\
Control & 74 & 81.2 & 7.5 & 6.7 & 1.98 \\
$\mathrm{~T}_{1}$ & 109 & 85.7 & 5.3 & 5.1 & 1.86 \\
$\mathrm{~T}_{2}$ & 92 & 80.1 & 8.0 & 7.4 & 1.94 \\
$\mathrm{~T}_{3}$ & 81 & 80.1 & 7.6 & 7.3 & 1.93 \\
Average & 89 & 81.8 & 7.1 & 6.6 & 1.93 \\
$\mathrm{~N}$ at sowing & & & & & \\
Control & 105 & 75.8 & 9.9 & 10.5 & 2.18 \\
$\mathrm{~T}_{1}$ & 146 & 79.6 & 7.7 & 8.0 & 2.00 \\
$\mathrm{~T}_{2}$ & 130 & 77.8 & 8.9 & 9.0 & 2.15 \\
$\mathrm{~T}_{3}$ & 122 & 76.4 & 9.0 & 8.9 & 2.14 \\
Average & 126 & 77.4 & 8.9 & 8.9 & 2.12 \\
LSD (1) & 24.6 & 3.59 & 1.45 & 1.08 & 0.14 \\
LSD (2) & 9.2 & 1.34 & 0.54 & 0.41 & 0.05 \\
Interaction & $\mathrm{ns}$ & $\mathrm{ns}$ & $\mathrm{ns}$ & $\star *$ & $\mathrm{~ns}$ \\
\hline
\end{tabular}


Table IV. Effect of foliar $\mathrm{N}$ fertilization upon $\mathrm{N}$ content of plant parts at maturity ( $\%$ of dry matter).

(1) Least significant differences between treatments within each fertility conditions. (2) Least significant differences between fertility conditions.

\begin{tabular}{|c|c|c|c|c|c|}
\hline Treatments & Total & Leaf & Stem & Grain & Chaff \\
\hline \multicolumn{6}{|c|}{ No $N$ at sowing } \\
\hline Control & 0.95 & 0.46 & 0.19 & 1.88 & 0.43 \\
\hline$T_{1}$ & 0.96 & 0.38 & 0.16 & 1.85 & 0.35 \\
\hline$T_{2}$ & 1.06 & 0.54 & 0.24 & 2.06 & 0.48 \\
\hline$T_{3}$ & 1.05 & 0.51 & 0.24 & 2.03 & 0.48 \\
\hline Average & 1.00 & 0.47 & 0.21 & 1.95 & 0.43 \\
\hline \multicolumn{6}{|l|}{$\mathrm{N}$ at sowing } \\
\hline Control & 0.76 & 0.40 & 0.21 & 1.65 & 0.37 \\
\hline$T_{1}$ & 0.88 & 0.40 & 0.21 & 1.76 & 0.45 \\
\hline$T_{2}$ & 0.91 & 0.46 & 0.22 & 1.96 & 0.47 \\
\hline $\mathrm{T}_{3}$ & 0.87 & 0.48 & 0.21 & 1.86 & 0.47 \\
\hline Average & 0.86 & 0.44 & 0.21 & 1.81 & 0.44 \\
\hline LSD (1) & 0.06 & 0.02 & 0.01 & 0.05 & 0.02 \\
\hline $\operatorname{LSD}(2)$ & 0.02 & 0.007 & 0.005 & 0.02 & 0.008 \\
\hline Interaction & * & $\star \star$ & \#* & $\star \star$ & $\star \star$ \\
\hline
\end{tabular}

supply, at this stage, favors survival of secondary tillers, in agreement with Scott et al (1977) and Power and Alessi (1978). In this work, high ear number per $\mathrm{m}^{2}$ at harvest was not associated with a lower harvest index, suggesting that density only has a negative effect on this index when there is a competition between these yield components that determine ear weight.

Nitrogen application at the end of tillering did not modify the number of spikelets per spike, because the apex was at the terminal spikelet stage; results do not agree with Dougherty et al (1978). Therefore, this yield component can only be altered when $\mathrm{N}$ availability increases near the double ridge stage (Langer, Liew, 1973).

In this work, differences in grain yield, where originated from modifications in grain number per $\mathrm{m}^{2}$, mentioned by many authors as the most important yield determinant (Scott et al, 1977; Sebillote et al, 1978; Evans, 1978; Spiertz, Ellen, 1978; Spiertz, 1979; Boiffin et al, 1981; Darwinkel, 1983). Nitrogen spraying at anthesis or post anthesis did not has any effect on grain yield and its components, in agreement with Sarandón et al (1986). Contrary to Coic (1960), grain weight was found to be insensitive to $N$ spraying, being high for this cultivar; this indicates adequate weather conditions and $\mathrm{N}$ availability during grain filling.

In wheat and barley, an increase in nitrogen availability decreases its translocation efficiency to the grain (Neales et al, 1963; Andersen, Koie,
1975; Halloran, 1981). Similar results were only found in the present study when $\mathrm{N}$ availability increased at sowing. Nitrogen application at this stage not only increased $\mathrm{N}$ uptake, but also the amount of $\mathrm{N}$ retained in the vegetative structures at maturity. However, the high nitrogen content in stems can be due to its higher weight and not to a lower translocation to the grain.

Fertilization at sowing decreased the $\% \mathrm{~N}$ in the grain, in agreement with Fernandez and Laird (1959) who worked with low $N$ doses at sowing. In the present experiment, despite the high $\mathrm{N}$ doses, greater $\mathrm{N}$ consumption at early developmental stages, might have later caused an $\mathrm{N}$ deficit which was enough to not affect grain weight but to decrease its $\% \mathrm{~N}$.

The increase in $\mathrm{N}$ distribution efficiency (NHI) at maturity in plots without $\mathrm{N}$ at sowing confirms that $\mathrm{N}$ translocation to the grain is stimulated by low $\mathrm{N}$ availability in the soil (Singh and Anderson, 1973). However, $N$ spraying at tillering improved both, $N$ uptake and $N$ partitioning efficiency to the grain, which disagrees with data obtained by Halloran (1981) working under controlled conditions. At field level $\mathrm{N}$ applications at tillering can improve dry matter distribution efficiency (harvest index) due to an increase of the sink (grain) and a decrease of the source (leaves, stems). Greater sink size induces great $\mathrm{N}$ demand by the grain, stimulating remetabolization and $\mathrm{N}$ translocation to the grain. When $\mathrm{N}$ level in the soil is a limiting factor, 
vegetative plant parts could not have enough $\mathrm{N}$ to satisfy grain demand, leading to a higher NHI and a lower grain \%N. Within this context it is unlikely that a direct relationship between $\mathrm{N}$ distribution efficiency $(\mathrm{NHI})$ and grain $\% \mathrm{~N}$ can be found. On the contrary, high soil $\mathrm{N}$ availability allows a response to $\mathrm{N}$ grain requirements, thus a high grain yield with high $\% \mathrm{~N}$ is obtained.

\section{CONCLUSIONS}

The present study showed that $N$ applications at sowing increased grain yield due to greater tiller production. However, this increase in the vegetative fraction can cause an early $\mathrm{N}$ consumption leading to $\mathrm{N}$ deficiency at the time some yield component of the ear is defined. It decreases head weight, dry matter distribution efficiency to the grain $(\mathrm{HI})$, and grain $\mathrm{N}$ percentage. Urea spraying at the end of tillering, as a complement of $\mathrm{N}$ applications at sowing modifies such a deficiency, increasing grain set, tiller survival and grain $\% \mathrm{~N}$.

In the absence of $\mathrm{N}$ applications at sowing, urea spraying at the end of tillering not only increases tiller production, grain yield and harvest index, but also grain $\mathrm{N}$ requirements, which could not be satisfied by the translocation of the $N$ previously stored in the vegetative structures. In this situation grain $\mathrm{N}$ percentage is reduced. Spraying performed at or in post anthesis does not affect yield, but increases grain $\% \mathrm{~N}$.

To generalize these conclusions it is necessary to study the effects of foliar fertilization in several cultivars, at different doses and developmental stages upon $\mathrm{N}$ uptake efficiency and its relationship with yield and grain protein content.

\section{ACKNOWLEDGMENTS}

The authors wish to thank Mrs Alicia Vega for her skillful technical assistance, the staff of Gorina Experimental Station for their assistance and cooperation in this assay, José Buck Breeder SA, for having provided the seeds, the Soil Department of the Secretary of Agriculture of Bs As for the soil analysis and Ing Agr DO Caldiz, for improving the english language. A grant was provided by the National Research Council (Conicet), through PID 3-017700/85, the Scientific Research Board of Buenos Aires $(\mathrm{CIC})$ and CAFPTA.

\section{REFERENCES}

American Association of Cereal Chemists Approved methods of the AACC 8th Edition
Andersen AJ, Koie B (1975) Nitrogen fertilization and yield response of high lysine and normal barley. Agron J 67, 695-698

Boiffin J, Caneill J, Meynard JM, Sebillotte M (1981) Elaboration du rendement et fertilisation azotée du blé d'hiver en Champagne crayeuse. I. Protocole et méthode d'étude d'un problème technique régional. Agronomie 7, 549-559

Coic $Y(1960)$ Les bases physiologiques de la nutrition et de la fertilisation rationnelle du blé. Progressive Wheat Production. Centre de l'Azote, Genève, 95-122

Darwinkel A (1979) Ear size in relation to tiller emergence and crop density. In : Crop Physiology and Cereal Breeding. Proc of a Eucarpia Workshop. Wageningen, The Netherlands. 1978

Darwinkel A (1983) Ear formation and grain yield of winter wheat as affected by time of nitrogen supply. Neth J Agric Sci 31, 211-225

Donald CM, Hamblin J (1976) The biological yield and harvest index of cereals as agronomic and plant breeding criteria. Adv Agron 28, 361-405

Dougherty CT, Love BG, Mountier NS (1978) Response surfaces of semi dwarf wheat for seeding rate, and levels and time of application of nitrogen fertilizer. NZJ Agric Res 21, 655-663

Dubois JB, Fossati A (1981) Influence of nitrogen uptake and nitrogen partitioning efficiency on grain yield and grain protein concentration of twelve winter wheat genotypes (Triticum aestivum L). Z Pflanzenzuecht 86, 41-49

Evans LT (1978) The influence of irradiance before and after anthesis on grain yield and its components in microplots of wheat grown in a constant day length and a temperature regime. Field Crops Res 1, 5-19

Fernandez R, Laird RJ (1959) Yield protein content of wheat in Central Mexico as affected by available soil moisture and nitrogen fertilization. Agron J 51, 33-36

Finney KJ, Meyer JW, Smith FW, Fryer HC (1957) Effect of foliar urea spraying of Pawnee wheat whith urea solutions on yield, protein content, and protein quality. Agron J 49, 341-347

Halloran GM (1981) Cultivar differences in nitrogen translocation in wheat. Aust $J$ Agric Res 32, 535-544

Johnson VA, Schmidt JW, Mattern PJ (1968) Cereal breeding for better protein impact. Econ Bot 22, 16-25

Kramer Th (1979) Yield-protein relationship in cereal varieties. In: Crop Physiology and Cereal Breeding. Proc of a Eucarpia Workshop, Wageningen, The Netherlands. 1978

Langer RHM (1966) Mineral nutrition of grasses and cereals. In: The growth of Cereal and Grasses. Proc of the 12th Easter School in Agricultural Science. University of Nottingham. 1965. (Milthorpe FL, Ivins JD, eds) Butterworths, London

Langer RHM, Liew FKL (1973) Effects of varying nitrogen supply at different stages of the reproductive phase on spikelet production and grain protein production and on grain nitrogen in wheat. Aust J Agric Res 24, 647-656 
Loffler CM, Rauch TL, Busch RH (1985) Grain yield and plant protein relationships in hard red spring wheat. Crop Sci 25, 521-525

Mesdag J (1979) Genetic variation in grain yield and protein content of spring wheat (Triticum aestivum L). In: Crop Physiology and Cereal Breeding. Proc of a Eucarpia Workshop, Wageningen, The Netherlands. 1978

Neales TF, Anderson MJ, Wardlaw IF (1963) The role of the leaves in the accumulation of nitrogen by wheat during ear development. Aust J Agric Res $14,725-736$

Power JF, Alessi J (1978) Tiller development and yield of standard and semidwarf spring wheat varieties as affected by nitrogen fertilizer. J Agric Sci Camb $90,97-108$

Sarandón SJ, Chidichimo HO (1985) Efecto de la densidad de siembra sobre la acumulación y redistribución del nitrógeno en 3 cultivares de Triticum aestivum L. Rev Fac Agron UNLP 61, 105-122

Sarandón SJ, Gianibelli MC, Chidichimo HO, Arriaga HO, Favoretti C (1986) Fertilización foliar en trigo (Triticum aestivum L). Efecto de la dosis y el momento de aplicación sobre el rendimiento y sus componentes, el \% de proteinas y la calidad del grano. Primer Congreso Nacional de Trigo. Pergamino, 1986. Tomo 2, 242-258

Scholz F (1984) Some problems and implications in improving cereal grain protein by plant breeding.
In: Genetics and Seed proteins. (Muntz K, Horstmann C, eds) Proc of the 3rd Seed Protein Symposium. Gatersleben, 1983. Kulturpflanze vol 32

Scott WR, Dougherty CT, Langer RHM (1977) Development and yield components of high yielding wheat crops. NZJ Agric Res 20, 205-212

Sebillote M, Boiffin J, Caneil J, Meynard JM (1978) Sécheresse et fertilisation azotée du blé d'hiver. Science du sol - Bull AFES 3, 197-213

Singh RP, Anderson RG (1973) Nitrogen and dry matter accumulation in dwarf varieties as influenced by nitrogen fertilization. Indian J Agric Sci 43 (6), 570-579

Spiertz JHJ (1979) Weather and nitrogen effects on rate and duration of grain growth and on grain yield of wheat cultivars. In: Crop Physiology and Cereal Breeding. Proc of a Eucarpia Workshop. Wageningen, The Netherlands. 1978

Spiertz JHJ, Ellen J (1978) Effect of nitrogen on development and grain growth of winter wheat in relation to assimilation and utilization of assimilates and nutrients. Neth J Agric Sci 26, 210-231

Terman GL (1979) Yield and protein content of wheat grain as affected by cultivar, N, and environmental growth factors. Agron J 71, 437-440

Tottman DR, Makepeace RJ, Broad H (1979) An explanation of the decimal code for the growth stages of cereals, with illustrations. Ann Appl Biol 93, 221-234 